\title{
UCLA
}

InterActions: UCLA Journal of Education and Information Studies

Title

Unpleasant Things: Teaching Advocacy in Archival Education Programs

Permalink

https://escholarship.org/uc/item/0408w1dv

Journal

InterActions: UCLA Journal of Education and Information Studies, 5(1)

ISSN

$1548-3320$

Author

Cox, Richard J

Publication Date

2009-02-20

DOI

10.5070/D451000643

Peer reviewed 


\section{Unpleasant Things: Teaching Advocacy in Archival Education Programs}

A lot has changed in the graduate archival education programs in both North America and worldwide in the past quarter century. There are more fulltime tenure-track and tenured faculty, course offerings richer in both depth and breadth, increasing research by both faculty and their students, and a growing number of doctoral students preparing for academic careers in archival studies. Although this is not fully reflected in every graduate program, the scholarship on archival theory and practice encompasses nearly every discipline and provides a much richer orientation to the meaning of archives in society (Cox, Yakel, Wallace, Bastian, \& Marshall, 2001). To be understood, these changes have to be put within the context of the transformation of higher education, the nature of students attracted to these programs, and vast changes in the kinds of issues faced by the modern archival community.

Higher education has become more corporate-minded-worried about the financial bottom line, assessments and benchmarks, accreditation, funded research, and the monetary worth of education. New students increasingly enter universities, even in the first of their undergraduate years, with an eye on practical skills and career goals rather than a quest for well-rounded learning. Archival educators are not immune to such matters, even at the graduate level, since archivists are also being challenged by the need to explain in very practical terms their programs and professional missions, as well as to justify the financial implications of their work. Such issues pressure the educators of archivists to stress practical training rather than deal with the more conceptual or theoretical aspects of archival work. There is a great temptation to stay close to matters that only aid their students to complete tasks such as figuring out how to generate revenue from their holdings rather than to promote fuller access, promote the importance of some holdings for social causes, or deal with testy legal or policy issues such as intellectual property and excessive government secrecy. In other words, basic concerns about practical issues and challenges might tend to overwhelm or squeeze out matters such as ethics, social justice, and equitable access because these are complicated, costly, and generally not captured in formulaic or prescriptive standards. This essay is intended to elaborate on such issues.

With the expansion in graduate archival education, the range of topics taught has also grown. Whereas 30 years ago these programs generally stressed archival descriptive practices and reference services (still considered by many as the core activities for at least entry-level archivists), now many also orient students to functions such as appraisal, advocacy, intellectual property, legal issues, specific documentary forms (such as still and moving images), and other matters that represent challenges to both the new students and the faculty teaching 
them. However, we still have a distance to go in how we consider archival work. Surprisingly, archival advocacy does not have a place in the most recent professional glossary (Pearce-Moses, 2005). The closest we come to it is "outreach": "the process of identifying and providing services to constituencies with needs relevant to the repository's mission, especially underserved groups, and tailoring services to meet those needs...Outreach activities may include exhibits, workshops, publications, and educational programs." I generally view advocacy to have a more specific aim of affecting a change in support, ranging from increases in resources, strengthened public policy and legislation, reaching new clienteles needing access to archives, and other actions extending beyond just better understanding of archives and the archival mission. The reference to addressing underserved groups perhaps indicates greater access across socioeconomic classes, ethnic and diversity barriers, or other social and political matters, but it has just as often meant no more than connecting with groups that have not normally been users of archives. In other words, archival outreach is a public relations process, whereas archival advocacy is a political process, encompassing all of the stresses and strains associated with working for political aims and teaching about them. Advocacy, therefore, does not always fit comfortably with the developing corporate university, which seems to embrace the nature of traditional professional schools stressing skills and credentials, usually in a manner supporting the status quo.

\section{Teaching}

Teaching has been likened to a performance, storytelling, and much more. A classic discourse on teaching promotes the idea that teaching is an art and a calling, arguing that although teachers master knowledge, they "distinguish knowledge from information" (Banner \& Cannon, 1997, p. 9). For these commentators, "information is to knowledge what sound is to music, the unorganized material out of which the structured result is composed. We do not ask teachers to convey information; we seek information from newspapers, the stock market ticker tape, or price tags on items in a store. Instead, we ask teachers to transmit knowledge, that which is organized and formally known about a subject-facts, findings, explanations, hypotheses, and theories accepted for their proven accuracy, significance, beauty, utility, or power" (Banner \& Cannon, 1997, p. 9). This is not as easy as it sounds, and, as one might surmise, it is a perspective some would disagree with, pointing to other ideas of socially constructed knowledge. The point here is that some of the same issues about knowledge, information, and evidence that provoke debate about the substance of teaching are also issues that could make it simultaneously exciting and exasperating to teach archival students about the nature of their mission and the 
meaning of archival sources (especially if all these students want is a set of basic tools for practice).

For one thing, students, undergraduate and graduate alike, are not always so receptive to knowledge, as opposed to information, sometimes because acquiring this is hard work, but more often than not because their attention is on more pragmatic matters (especially in these difficult economic times). And sometimes their lack of receptivity is because they read and believe claims made by universities that their educational programs will equip them for lucrative careers. Jacques Barzun (1992), drawing on more than a half century of his observations about teaching at all levels, makes many astute observations about the challenges of teaching, observing that college students "want education for their souls, training for life, organized social and artistic activities, psychiatric help, and career planning and placement" (p. 157). Sometimes they seem to want this in one course. And, as I have observed, the interest in pragmatic training and skills acquisition only intensifies in graduate programs in professional schools (especially as the prospects for acquiring an entry-level position become more competitive and the costs of education rise).

The role of the professor in the university has been challenged, broadened, redefined, and attacked in numerous ways in the past few decades. Classicist James J. O'Donnell (1998) suggests that the "real roles of the professor in an information-rich world will be not to provide information but to advise, guide, and encourage students wading through the deep waters of the information flood. Professors in this environment will thrive as mentors, tutors, backseat drivers and coaches" (p. 156). Others, from within the university, still see such clusters of roles as falling far short of what they should be. Jane Tompkins, an English professor, seeks a "holistic" approach to working with students, or, as she explains: "There's too much emphasis on matters related exclusively to the head and not enough attention given to nurturing the attitudes and faculties that make of knowledge something useful and good" (Tompkins, 1996, p. 206). Another English professor, writing from the depths of the so-called culture wars, enthusiastically embraces such conflicts because of conflicting missions (Graff, 1992) of the university: "The university is expected to preserve, transmit, and honor our traditions, yet at the same time it is supposed to produce new knowledge, which means questioning received ideas and perpetually revising traditional ways of thinking" (Graff, 1992, p. 7). Those of us in professional schools are more acutely aware of such contradictions, as we face them in the classroom every day (or, at least, so it seems). Such commentators, besides providing evidence of sometimes very contradictory notions about the role of faculty, also provide some hope for academics frustrated by the challenges they find in teaching and advising students. Tompkins' assessment, for example, can be seen as prodding faculty in professional schools to go beyond conveying skills, 
constructing tools, and disseminating practical information to both challenging and consoling students who will face more complicated scenarios in their careers than those encountered by earlier generations.

All of these resources are necessary when we teach new groups of aspiring archivists, especially when we need to shake them from their preconceptions of archival work to be equipped to advocate for their institutions and their profession in a world with increasingly complex challenges for archival work. We need to be able to deconstruct these students' notions, challenge them by presenting the realities faced in archival work, and then mentor them to a level of confidence so that they can function with success. This is an often difficult process given the notions of archives and career goals that students bring to these graduate programs, especially so since this is a process often leading to counseling students out of their vocational aims (contrary to the idea of students as customers-so often touted in the corporate university model-who shape their own expectations). While respecting our students and their personal goals, we also need to push them to understand that their perceptions of archival work may be highly flawed.

\section{Professional Schools}

There has been a flurry of writing about the corporate nature of the university, with a shift to the primary concern for the bottom financial line rather than higher ideals for educating students and a mission to improve society. Derek Bok, as one example, in reviewing the many complaints leveled against the university, argues that these complaints can't be lightly dismissed, although he reminds us just how difficult it can be to present a concise or unified view about the purpose of higher education: "Anyone seeking a common purpose must go all the way back to a time before the Civil War, when colleges united around a classical curriculum aimed at mental discipline and character building" (Bok, 2006 , p. 24). Bok traces a shift to vocationalism, the role of teaching writing and speaking, the challenges posed by trying to teach students to think, the issues of focusing on building character or making good citizens, the concern about diversity among students and faculty, the meaning of the global society, and a variety of other compelling and contentious issues.

Vocationalism is at the heart of professional schools located in universities. With the pressure of high tuition costs and the search for particular skills or credentials, faculty in professional schools must be prepared to explain and justify why they teach what they teach and have thick skins to hear complaints when students fear they are the recipients of impractical theories and ungrounded knowledge. One might believe that introducing students to the realities of archival work would assuage such concerns, yet these realities also can 
upset students' preconceived notions of archival work and future archival careers. Students often expect that they will be working immediately with archival documents and see the classroom as an extension of an apprenticeship system; they grow impatient when, instead, they are immersed in the philosophical and theoretical dimensions of archival work. Instructors understand this is the main opportunity to orient students to the foundation of archival knowledge, but students are not easily mollified by the explanations supporting this approach. Here is where we need to sensitively challenge students to consider the real fit of the archival mission, and sometimes the controversies about that mission, in the real world.

One might wonder, if there is a leaning to compelling interests in vocations and practical knowledge, why professional schools might not be thriving in universities. The prominence of professional schools presents a challenge when reflecting on how to equip students as future archivists to become better advocates for their discipline and professional mission. Professional schools have had a prominent place in the modern university since the late nineteenth century in the United States. When we consider European versions of professional schools, we can find them dating back to the early nineteenth century and, occasionally, even into the seventeenth century; they are not new entities at all. And, when we consider the very practical curricular programs of the earlier university or college, we can argue for an even older foundation of these professional programs. Examinations of these schools demonstrate that they were always striving to bring together the university mission of knowledge generation and its application in the real world.

We can even discern these earlier histories of professional education when we look at the history of our own early professional schools for archives. A recent history of France's Ecole des Chartes, widely known by archivists to be the spawning ground for many elements of modern archival theory and practice, demonstrates that many of the ideas developed there were in reaction to political, economic, and social challenges (or realities) of the day (Moore, 2008). Moore shows how the mission and approach of the Ecole des Chartes shifted a number of times in response to changing governments and political trends, debunking any idea that somehow the origin of the modern archival profession was immune from such influences. In considering their work in classification, inventorying, inspection, and centralization, Moore argues that "archives . . . were linked with the controlled production of national history, which was seen as essential to political unity and stability" (p. 195). We still see this today, although the archival movements of the disenfranchised, fringe groups, and oppressed speak to how complicated the notion of archives has become.

What professional schools bring to the fore is the tension between the generation of new knowledge-a traditional aspect of the mission of 
universities - and the training of individuals who want to learn skills and methods and who want a credential for entry into a professional community. Moore's history of the Ecole des Chartes provides a case study of this. Although one of the hallmarks of the rise of the modern university in the past century has been the creation of professional schools and the development of disciplines, the professional schools have often had a tenuous, stormy relationship to the university. One of the greatest challenges is a divided loyalty between working practitioners and the demands of the research university, the mission of universities, and the challenges facing universities. This has been well documented in studies of some of the preeminent examples of professional schools, such as in education and business (Khurana, 2007; Labaree, 2004). Graduate archival education programs face a slightly different scenario, since these are programs within library and information science schools (or the more recent manifestation of these schools, "I-Schools" or Information Schools); while these schools have existed since the late nineteenth century and have been the topic of much soul-searching about their utility, purpose, and future, they have not received the full-scale study that other professional schools have been given. However, the location of most of the graduate archival programs in such schools - institutions with a heavy emphasis on professional skills and attitudesmay contribute to some of the perspectives new students bring with them (for examples, see Dillon \& Norris, 2005; Gorman, 2004; and Holley, 2003).

Many faculty of professional schools struggle with their self-identification as faculty in a university, torn as they are between professions with their own practical agendas and research and publication involving the building of knowledge and theory. If faculty members engage in building a body of scholarship, the very professions in which they supposedly equip new practitioners to work may chide them, and if they focus on teaching to prepare these practitioners, they may be shunned in their own schools for a lack of productivity. However, it is possible to look at this as a creative challenge. Immersing themselves in the most pressing issues of the present corps of practitioners may lead these faculty members to engage in new forms of scholarship that can press the profession to re-examine its own roots, principles, and assumptions. In my own career, I have found it remarkably interesting to wrestle with such problems; while it may not win one popularity contests, such work constantly revitalizes one's own teaching and research. The professional school may be a troubling place for some, but it can also be a place of great energy. And, when properly engaged, new students with new perspectives can help greatly to energize this process and generate new ideas for the profession itself.

How does this play out in graduate archival programs, most of which are located in professional schools (library and information schools or I-Schools) or 
function as professional schools when located in other university departments (principally history departments)? There has been a major transformation in graduate archival education in the past quarter century in the United States and in a number of other countries, mostly reflected in the growth of full-time regular faculty members, the proliferation of archival journals, an increase in research monographs (some the result of the increasing number of dissertations being done in the field), and expansion of the curriculum. What has not fundamentally changed, in any noticeable way, is why students come to the archival programs to prepare for their careers.

\section{Why People Want to Be Archivists}

Most individuals come into graduate archival education programs because they love history, old stuff, personal collecting, or have been inundated by the documentary debris of the past because of family and other personal experiences. When I ask my own students to write about why they want to be archivists, I learn about their exposure to reading old family papers or learning to take care of them, personal collecting, diary or blog writing, and a deep love of history often nurtured by visits to historic sites or even the reading of historical fiction. Some of this is not particularly surprising (if for no other reason than that most archival educators can identify with these reasons because they mirror many of their own personal motivations). Students from undergraduate and graduate history programs, for example, have been coming into archives programs for a very long time. Indeed, it is a persistent theme in the archival professional literature, extending back many decades, and at one time was the stimulus for great debate about the location and nature of graduate archival education programs. Now peace reigns about such issues, although there are obvious differences between programs when their course offerings and faculty perspectives are examined.

Many students enter graduate archival education programs because they discovered the profession when seeking an on-campus job as an undergraduate or because of volunteer work done or other part-time paid positions. Many developed interests in the archives field because of varied work experiences, such as the mortgage industry, banking, newspaper reporting and journalistic research, paralegal work, and social work, as well as in other fields where recordkeeping played a key role and consumed considerable time and energy. I have witnessed a growing number of people who become interested in archives because of visits to historic sites, historic homes, battlefields, and museums. Not all of these explicitly proclaim anything about archives or archivists (although some feature exhibitions with archival documents and nurture an interest in the past). Nearly every kind of archives position is represented by such experiences, although, not surprisingly for the youngest students, academic archives and special collections experiences 
while undergraduates predominate. These reasons have remained stable over time, as David Wallace's (2000) survey of a decade ago affirms. Since we know very well that the work of the archivist is not a high-profile profession, such experiences may be the predominant means by which individuals discover the field. The interests and experiences we see new students bringing with them suggest why it is difficult to teach certain more complicated and challenging aspects of archival work, such as advocacy, to these students.

\section{The Challenge of Teaching Archives Students}

What motivates individuals to become archives students is generally what makes it difficult to teach them about the challenges of archival administration in the present day, especially in matters related to archival advocacy. Those interested in history, for example, will need to learn some disturbing facts, such as that archivists split from professional historians, and there are still scars and open wounds caused by this. In fact, while most users of archives can be said to be doing historical research, it is probably the case that most are not professional historians (they are sociologists, anthropologists, family historians, journalists, and others ranging from high school to doctoral levels of education). However, archival studies (or science, as some insist on calling it) is generally seen as an interdisciplinary or multi-disciplinary field, suggesting that there are disciplines with important roles to play as well (try library and information science for starters). Those interested in archives because of historic sites or museums need to learn that while these organizations employ archivists, there are substantial differences between museum, public history, library, and other fields' work and what archivists do.

A small portion of individuals entering graduate archival education programs arrive there because they have read something that motivated them to consider archival work as a vocation. My personal favorite, and I see this regularly, is the reference to Nicholson Baker's Double Fold (2001), a literate rant about Baker's perceived concerns and problems about preservation that not only disparages the value of formal education but is a book that confuses the library and archives fields and their missions; it troubled me enough to write a booklength response (Cox, 2002). Baker's book still draws more attention to the preservation issue than any other book in recent memory. It is curious to me that some readers thought that Baker was a professional librarian rather than the novelist and essayist that he is, especially since young students and novice archivists also indicate that they have been influenced by encountering fictional archivists in novels and mysteries, and learning something about what archivists do. The problem with such influences is that they often feed the popular stereotypes young students bring with them - that archives are quiet places for 
people to work, unbothered by the troubles of the world or the challenges of relating to diverse communities and individuals. Archivists' responsibility to work with records today places them directly in the crosshairs of legal challenges, intensive media scrutiny, complex compliance situations, and contentious squabbles over everything from ownership of intellectual property to repatriation battles about documents and artifacts. These are not monastic positions where one withdraws from worldly cares.

It would be unfair if I implied that students come into graduate archival programs totally naïve and uninformed. Some, in fact, bring with them interesting questions and challenging concerns that have also energized debates among experienced archivists and those who are composing theoretical models for archival work or conducting research to refute or endorse older, newer, and emerging frameworks for archival epistemology. One recent group of students at my own program brought with them issues about the changing nature of the document, how to contend with practical archival challenges in current places of employment, social and political issues affecting the nature of the archival field and its societal mission, censorship and privacy issues and debates, the relevancy or validity of the claims for a new profession (will we be digital curators in the future rather than archivists?), and the nature of the fiscal management of archival material. As I will suggest shortly, it is easy to engage such students about matters such as archival advocacy, but it is also likely the case that these are in a distinct minority among all the students.

As I indicated above, it is the nature of professional schools that they draw people who are searching for a livelihood and a credential for pursuing a vocation, focused on practical skills rather than theory, and interested in a paycheck for doing something that interests them rather than in some grand societal mission and narrative. These kinds of students often offer candid assessments of preparing for archives positions as a pragmatic means to pursuing interests in history, film studies, museums, and rare books and special collections (when getting into these fields may be quite difficult otherwise), as well as the bigger concern for acquiring food, shelter, and the other basics of survival. These may be the students who have the hardest time grappling with the real challenges archivists and archives are actually facing today, especially when confronted with such matters early in their educational programs, as they must be.

\section{The Reality of Being An Archivist, or the Heart of Archival Advocacy}

Most experienced archivists assume the importance of the archival mission in society. They soon encounter the reality that society doesn't always comprehend the mission or, if it does, that it does not always support it in very useful ways. Sometimes the lack of understanding can be funny, although 
archivists do not always see the humor in such matters. For example, in the midst of writing this essay, I learned that Laurence Shatkin, author of The 150 Best Low-Stress Jobs, considers the archivist one of those low-stress jobs. Salemi (2008), citing Shatkin, reports that "this occupation focuses on planning and overseeing the arrangement of exhibitions of collections, there's a certain degree [of] consistency and low stress levels" because people who control their tasks have lower stress factors. She also notes that only a bachelor's degree in history or library science is required-clearly inaccurate - and that the average salary is over $\$ 40,000$ (also probably more misleading than a question of not being very accurate). The Archives Next blog (http://www.archivesnext.com/) also includes information from Shatkin, who reveals that his information is based on statistics available from the U.S. Department of Labor. To no one's surprise, archivists have reacted negatively to this assessment.

My own sense, however, is that many people are initially attracted to this field because of notions such as those expressed by Shatkin, and then they discover that there are many more challenges to archival work that they did not anticipate. For example, most students never assume that they will have significant administrative responsibilities, anticipating that they will work quietly with collections documents and artifacts. The kinds of advocacy activities that archivists engage in-from fundraising and other work to gain financial support, to lobbying for improved government legislation, to jockeying for recognition for archival programs within various institutional settings-are hardly ever listed as reasons why students arrive at graduate archival education programs to prepare for archival careers. One of the challenges for archival educators is determining how to introduce students to and equip them for the realities of archival work. Another challenge is for archival educators themselves to learn about and develop teaching materials for these realities.

\section{Teaching Unpleasant Things}

In my own career as an educator I have evolved in ways I never anticipated when I started two decades ago. When I first began teaching about archival administration, I covered the basic functions of this work, including orienting students to issues about how to advocate on behalf of their programs within their employing institutions and in society in general. In fact, I considered nearly aspect of what I taught to be a form of archival advocacy because it involved grounding students in how to think more expansively about the responsibilities of archivists than the preconceptions they brought with them (Cox, 1997). As time has passed, however, I have more fully developed ideas about the archival mission to encompass the importance of evidence in recordkeeping, the role of records for accountability in organizations and 
governments (extending far beyond archives as just cultural enterprises), and archives as memory institutions (a concept that expands the cultural mission in profound ways). This has required me to be involved in working with others to build new kinds of case studies (for use in the classroom) than the archival community has normally prepared (Cox \& Wallace, 2002) or to enter into public debates with those who have critiqued the archival mission in ways that deserve detailed responses (such as my response to Nicholson Baker).

Over the past couple of decades, the archival profession has mostly seen digital technologies as its greatest issue, and with good reason. These technologies have threatened both the ability of archivists to preserve records and the basic nature of archival work and identity. Clearly a significant part of dealing with the archival issues of the Digital Era involves more effective advocacy, as archivists build new partnerships, lobby for greater resources to solve these issues, and readjust some of their most basic assumptions, such as physical custody and acquisition of archival materials. For example, archivists' ability to take physical custody of new digital forms of personal archives, such as web sites and blogs, may require that the profession adopt new ways of working with society to ensure the preservation of our documentary heritage, a topic I explore in a new book (Cox, 2008). However, I am not convinced that these are the most serious issues facing archivists today. There are indicators of success with digital recordkeeping, and as society becomes more aware of the challenges of the longterm maintenance of digital documents, there will be an increasing array of commercial and other solutions for solving these challenges.

The most prominent problems for the foreseeable future may be more ethical and accountability issues, or, to put it another way, the ways that these new technologies can be utilized to invade personal privacy, erode government and corporate accountability, restrict intellectual property, and cause other problems. All of these kinds of issues involve equipping a new generation of archivists to become more effective advocates for their programs, working more actively within their professional associations, and engaging society so that it understands archival work and the archival mission.

These are not easy issues to address, and they are sometimes topics guaranteed to affect (negatively) teaching evaluations. In one particularly tempestuous year, I witnessed a group of students in near revolt, complaining that I was preparing them for how to lose their jobs, by whistle-blowing and other means, even before they had secured their first position. They have a point, and I must admit that teaching advocacy requires fine-tuning performance so that the instructor does not come across as overly critical, obsessed with all the injustices of the world, or presenting an overly depressing view of the future of the profession. Fortunately, however, there are always successes to point to when considering teaching issues such as these. 
In my primary course dealing with the topic of archival advocacy (Archival Access, Advocacy, and Ethics), I have students examine specific cases relating to the broad topics covered by the course. In the most recent version of this course, I had students write brief ( 5 to 10 pages) papers about any two of the three areas, with one of the areas being "some aspect of archival advocacy or public programming." Students were also given the option of building on earlier papers done in the introductory archives course if the topics of these papers meshed with the themes of the later course. A number of fine papers were prepared, and I selected three that were closely related (dealing with the ownership and control of the records of indigenous peoples, the use of government records created as part of the normal procedures of the Supreme Court, and the misadministration of electronic mail messages generated by the George W. Bush White House) to create a mock conference session (Archival Accountability and Ethics in the Real World: Three Cases) and to give students the experience of what such sessions are like. I then worked with these students to prepare one essay for publication, part of a forthcoming special issue of Library and Archival Security to appear in the spring of 2009 and also including other student papers from this course. This exercise led to many interesting discussions about the kinds of issues about which archivists need to advocate and how such advocacy might occur. At the same time, it contributed to the professional literature that can be drawn on for professional advocacy. The stress on case studies may compensate for one of the major expectations students have in these graduate programs - the desire for practical experience; the process of delving into a real-life case enables students to examine first-hand how archivists work and how archives fare in our modern society.

The other aspect of teaching archival advocacy in some graduate archival education programs occurs in working with doctoral students. Obviously there are two benefits in engaging doctoral students in archival advocacy issues. First, they may develop research and scholarship on archival advocacy that can enrich professional discussions and activities. Most of my own doctoral students have worked on topics related to accountability, memory, archival policy, and access that have made such contributions (Marshall, 2006; Sinn, 2007; Wallace, 1997; Whorley, 2006). Second, these individuals will fill academic positions, mostly as full-time, tenure-track faculty but perhaps also as adjuncts. Equipping them to teach their students about archival advocacy and to develop research agendas to support such a curriculum will have long-term positive benefits. In schools where there are both masters and doctoral students, doctoral students can often be called upon to teach their cases and to mentor masters students.

\section{Conclusion: A Richer Context}


The literature supporting teaching archival advocacy and related topics has grown immensely in the past two decades (rather than trying to provide a list of such literature, I refer readers to my blog, "Reading Archives." Some of it has been written from inside the archival community, but a remarkable array of literature from outside has focused on the nature of archives and recordkeeping, public memory, truth commissions, privacy, intellectual property, digital information, networking, public policy, and many other topics, all raising considerable issues and questions about what archivists do. This literature strengthens and challenges us to deal with how the archival enterprise fits within society, and it certainly makes it easier to engage students in aspects of the field that they have taken for granted. The nature of this literature also orients students to a variety of theoretical approaches to the nature of the archive. Helen Buss, in an introduction to a collection of essays about using women's archives, gives us an example of this: "Feminist scholarship allows for the special passion we feel for the archives of those close to us, encourages the full revelation of bias and highlights the sophistication of the insightful readings that emotional attachment brings by an attention to theorization" (Buss \& Kadar, 2001, p. 4). When they leave a graduate archival education program, students should have different ideas about what an archivist does and the problems they face-and why they need to be articulate advocates for the archival mission-than when they came. Otherwise, we have failed to teach them.

There can be a cost for faculty teaching a subject such as this. In one of the best books on teaching in higher education, Ken Bain (2004) stresses the need to always have an eye on students' learning and thinking abilities rather than on short-term skills or other approaches (sometimes aimed at little more than generating good teaching evaluations for faculty members). The evolution of this particular course (LIS 2223 Archival Access, Advocacy, and Ethics) from a focus mainly on reference room activities to one that deals with substantial issues challenging archival work, such as ethical misdeeds or reformulating the nature of the archival mission, has also prompted me to look beyond immediate student evaluations to consider criteria such as contributions to the published professional and scholarly literature. Some of the more immediate contentious responses by some students concerning the topics taught in this course are mitigated by a sense of more substantial products created by the students taking the course. Some students complain about the theoretical slant of the course, and this is a complaint posed mostly against what they see as the lack of hands-on experience and before they are exposed to postmodern, feminist, cultural studies, and other theoretical visions of what the archive represents. In this manner, I am teaching something about the nature of archival advocacy by being an advocate myself for a different archival mission, one open to being influenced by forces outside the professional community. My goal is to transform what often are romantic, naïve 
understandings of archival work into a more dynamic version of the archival mission suitable for the rapidly changing Digital Era.

\section{References}

Bain, K. (2004). What the best college teachers do. Cambridge: Harvard University Press.

Baker, N. (2001). Double fold: Libraries and the assault on paper. New York: Random House.

Banner, J. M., Jr., \& Cannon, H. C. (1997). The elements of teaching. New Haven: Yale University Press.

Barzun, J. (1992). Begin here: The forgotten conditions of teaching and learning. Chicago: University of Chicago Press.

Bok, D. (2006). Our underachieving colleges: A candid look at how students learn and why they should be learning more. Princeton: Princeton University Press.

Buss, H. M., \& Kadar, M. (Eds.). (2001). Working in women's archives: Researching women's private literature and archival documents. Waterloo, Ontario, Canada: Wilfrid Laurier University Press.

Cox, R. J. (1997). Advocacy in the graduate archives curriculum: A North American perspective. Janus, 1, 30-41.

Cox, R. J. (2002). Vandals in the stacks? A response to Nicholson Baker's assault on libraries. Westport, CT: Greenwood Press.

Cox, R. J. (2006). Ethics, accountability and recordkeeping in a dangerous world. London: Facet.

Cox, R. J. (2008). Personal archives and a new archival calling: Readings, reflections and ruminations. Duluth, MN: Litwin Books.

Cox, R. J. (2009). "Reading Archives.” http://readingarchives.blogspot.com/

Cox, R. J., \& Wallace, D. (2002). Archives and the public good: Accountability and records in modern society. Westport, CT: Quorum Books.

Cox, R. J., Yakel, E., Wallace, D., Bastian, J., \& Marshall, J. (2001). Archival education in North American library and information science schools. Library Quarterly, 71(2), 141-194.

Dillon, A., \& Norris, A. (2005). Crying wolf: An examination and reconsideration of the perception of crisis in LIS education. Journal of Education for Library and Information Science, 46(4), 280-298.

Gorman, M. (2004). What ails library education? The Journal of Academic Librarianship, 30(2), 99-101.

Graff, G. (1992). Beyond the culture wars: How teaching the conflicts can revitalize American education. New York: W. W. Norton.

Holley, R. P. (2003). The ivory tower as preparation for the trenches. College and 
Research Libraries News, 64(3), 172-175.

Khurana, R. (2007). From higher aims to hired hands: The social transformation of American business schools and the unfulfilled promise of management as a profession. Princeton: Princeton University Press.

Labaree, D. (2004). The trouble with ed schools. New Haven: Yale University Press.

Marshall, J. A. (2006). Appraising for accountability: A comparative case study of appraisal documentation at the National Archives and Records Administration, the National Archives of Canada, and the National Archives of Australia. Doctoral dissertation, University of Pittsburgh.

Moore, L. J. (2008). Restoring order: The Ecole des Chartes and the organization of archives and libraries in France, 1820-1870. Duluth, MN: Litwin Books.

O'Donnell, J. J. (1998). Avatars of the word: From papyrus to cyberspace. Cambridge: Harvard University Press.

Pearce-Moses, R. (2005). A glossary of archival and records terminology. Chicago: Society of American Archivists. Retrieved February 11, 2009, from http://www.archivists.org/glossary/

Salemi, V. (2008). Relax: Find a low-stress job with high potential. Retrieved September 24, 2008, from http://hotjobs.yahoo.com/career-articlesrelax_find_a_low_stress_job_with_high_potential-516

Sinn, D. (2007). Records and the understanding of violent events: Archival documentation, historical perception, and the No Gun Ri massacre in the Korean War. Doctoral dissertation, University of Pittsburgh.

Tompkins, J. (1996). A life in school: What the teacher learned. Cambridge, MA: Perseus Books.

Wallace, D. A. (1997). The public's use of federal recordkeeping statutes to shape federal information policy: A study of the PROFS case. Doctoral dissertation, University of Pittsburgh.

Wallace, D. A. (2000). Survey of archives and records management graduate students at ten universities in the United States and Canada. American Archivist, 63(1), 284-300.

Whorley, T. (2006). The Tuskegee syphilis study: Access and control over controversial records. Doctoral dissertation, University of Pittsburgh.

\begin{abstract}
Author
Richard J. Cox is Professor in Library and Information Science at the University of Pittsburgh, School of Information Sciences where he is responsible for the archives concentration in the Master's in Library Science degree and the Ph.D. degree. He has been a member of the Society of American Archivists Council
\end{abstract}


from 1986 through 1989. Dr. Cox also served as Editor of the American Archivist from 1991 through 1995 and Editor of the Records \& Information Management Report from 2001 through 2007. He has written extensively on archival and records management topics and has published fourteen books in this area. Dr. Cox was elected a Fellow of the Society in 1989. 